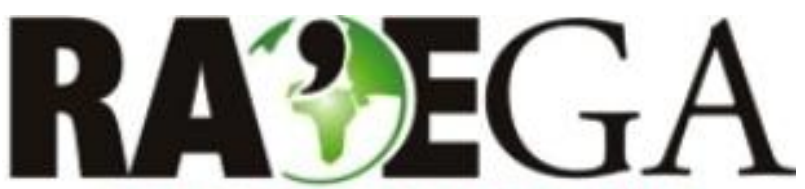

O ESPACYO GEOGRÁFICO EM ANÁLISE

\title{
ESTRATÉGIAS IMOBILIÁRIAS E A CONSTRUÇÃO DO “MITO” DO PAI DOS POBRES NA PRODUÇÃO DOS BAIRROS PERIFÉRICOS DE AMORAS E NOVA VIÇOSA (1970-1990)
}

\section{REAL STATE STRATEGIES AND CONSTRUCTION OF THE "MYTH" THE FATHER OF THE POORS IN PRODUCTION OF PERIPHERAL ZONE OF AMORAS AND NOVA VIÇOSA (1970-1990)}

\author{
Dayana Debossan Coelho \\ Mestranda em Geografia pela Universidade Federal de Juiz Fora (UFJF) \\ Departamento de Geografia \\ Juiz de Fora, $M G$ \\ e-mail: dayanadebossan78@gmail.com \\ Maria Isabel de Jesus Chrysostomo \\ Professora da Universidade Federal de Viçosa (UFV) \\ Departamento de Geografia \\ Viçosa, MG \\ e-mail: isachrysostomo@ufv.br
}

\section{Recebido em: 28/04/2014}

Aceito em: 06/02/2015

\section{Resumo}

Este trabalho discute as formas de segregação urbana a partir do nascimento de Amoras e Nova Viçosa, dois bairros populares localizados na periferia de Viçosa, Minas Gerais. A pesquisa teve como objetivo principal identificar o papel dos sujeitos responsáveis pelo nascimento destes bairros, os problemas enfrentados pelos moradores durante o processo de constituição e as formas de apropriação capitalista do solo. É nosso intuito discutir o papel da propaganda e as práticas clientelistas empregadas pelos agentes imobiliários para viabilizar os seus empreendimentos. A história de Amoras e Nova Viçosa demonstra como os atores locais (re) significaram as estratégias de capitalização adotadas em outras escalas geográficas. $O$ personagem de Antônio Chequer exemplifica estas práticas de capitalização do mercado de terras, ao se notabilizar como maior empresário da construção civil de 
Viçosa (MG). Além disso, seu exemplo demonstra o empoderamento político que foi criado pela imagem propagandeada pela imprensa e legitimada nas várias campanhas eleitorais. Carregando a bandeira em prol dos menos favorecidos, "dos marginalizados" e oprimidos, as imagens de Chequer esconderam os benefícios e privilégios conquistados por ele durante a sua trajetória de vida. Neste aspecto omitem os seus interesses de lucro projetados nesses novos espaços periféricos.

Palavras-chave: periferia, propaganda, agentes imobiliários.

\begin{abstract}
This paper argue the forms of urban segregation from birth of Amoras and Nova Viçosa, two popular neighborhoods located in the periphery of Viçosa, Minas Gerais. Research had as main objective identify the role of responsible subjects for the birth of these neighborhoods, the problems faced by residents during the process of constitution and the forms of capitalist appropriation of the soil. We aim to discuss the role of advertising and the clientelistic practices employed by real estate agents to facilitate their endeavors. The history of Amoras e Nova Viçosa demonstrates how local actors (re) meant capitalization strategies adopted in other geographical scales. The character of Antonio Chequer exemplifies these practices of capitalization of land market, to become known as the largest construction businessman of Viçosa (MG). In addition, your example demonstrates the political empowerment that has been created by the propagandized image in the media and legitimized in several election campaigns. Carrying the flag on behalf of the less fortunate, "marginalized" and oppressed, Chequer images hid the benefits and privileges earned by him during their life course. In this respect omit their profit interests in these new peripherals designed spaces.
\end{abstract}

Keywords: periphery, advertising, estate agents.

\title{
1. INTRODUÇÃO
}

[...] Com a expansão da Universidade, Viçosa precisou de uma mercadoria chamada habitação. (...) E com a criação de Nova Viçosa houve um chamamento da zona rural não só de Viçosa, mas dos municípios vizinhos: Canaã, Coimbra, Porto Firme, Guaraciaba e outros, que vieram para Viçosa em busca de trabalho, de uma nova vida e de um lugar de seu para morar (CHEQUER, 1989 in SANTOS, A. M. C., 1991).

O trecho retirado de uma entrevista concedida pelo maior empreendedor imobiliário de Viçosa desde a década de 1970 ilustra as mudanças sociais, econômicas e políticas que ocorriam nas cidades brasileiras em decorrência da 
"modernização conservadora" do campo e do crescimento das cidades. Neste contexto, Viçosa transforma-se de forma radical: quase metade de seu território foi loteada por Antônio Chequer que além de empreendedor imobiliário, tornou-se prefeito e vereador da cidade em diversos mandatos. Neste movimento nascem paralelamente as periferias urbanas e os bairros de classe média em Viçosa. E emerge também o mito Antônio Chequer, que se torna figura memorável na vida e na cultura dos viçosenses em função da criação, venda e doação de lotes de terra em muitos bairros da periferia.

Buscando compreender como este processo ocorreu e seus principais desdobramentos sociais, o presente trabalho almeja constituir um esforço de reflexão acerca do nascimento de dois bairros dessa periferia urbana - Nova Viçosa e Amoras. É nossa intenção analisar como se constituiu o mito Antônio Chequer (proprietário de uma das mais importantes imobiliárias da cidade), identificando as estratégias de promoção política desse personagem na criação destes dois bairros, em especial o de Nova Viçosa. Além disso, buscamos confrontar os dados da realidade destes bairros (quantidade de lotes doados, infraestrutura, condições de habitabilidade...) com as imagens e representações construídas pelos principais meios de comunicação, cuja intenção era propagar a figura de Antônio Chequer como benfeitor dos pobres da cidade e grande liderança política local.

Ao analisarmos o nascimento desses bairros observamos a construção de uma narrativa sobre a questão habitacional, cujo intuito era resolver, ao nível simbólico e imaginário, as tensões, os conflitos e as contradições da realidade social vivida, ou seja, os problemas decorrentes da falta de moradia. Neste aspecto, com a criação destes dois loteamentos funda-se o mito da solução da moradia, omitindo os conflitos relacionados à apropriação do solo pelos incorporadores imobiliários ${ }^{1}$. Isto é, tal mito foi estrategicamente elaborado pelas lideranças locais para camuflar os

\footnotetext{
${ }^{1}$ Como discute Chauí (2003) o mito nas sociedades modernas marca uma ruptura do pensamento filosófico tradicional. Ele é, via de regra, um sistema explicativo criado na maioria das culturas para oferecer uma chave de compreensão e origem e justificar os diversos aspectos e tensões existentes na sociedade. O mito como uma solução imaginária cria uma outra realidade, constituindo-se de, certa forma, em um mecanismo para conservar a sociedade e evitar a sua desagregação.
} 
principais problemas da cidade - a falta de acesso à terra urbana para os pobres e a pouca incidência dos programas habitacionais. Portanto, a questão do direito à moradia, este "fundo invisível" e tenso vivenciado pelos viçosenses, foi transformada pelos propagadores deste mito numa solução imaginária para os pobres recémchegados e que foram proibidos de construir suas casas e ter acesso às infraestruturas urbanas situadas nas áreas centrais.

O nascimento das periferias em Viçosa ilustra como os atores das pequenas cidades criam estratégias para ser apropriar do solo tendo em vista os processos de urbanização capitalista que se desenvolvem em outras escalas espaciais. $\mathrm{O}$ mito em torno do qual se estruturou o personagem Antônio Chequer mostra, nesse sentido, como os espaços situados nas "margens" do capitalismo revelam práticas espaciais segregacionistas entre as quais a territorialização material e simbólica de várias áreas da cidade.

Os casos de Nova Viçosa e Amoras, que elegeremos para nossa reflexão, resultam desses mecanismos sociais: uma mescla entre clientelismo, personalismo, propaganda, crescimento econômico dos setores de construção civil e imobiliária e apropriação oligopolista do solo. Esses processos, que se espraiam de forma violenta nas pequenas cidades, marcam a paisagem dos espaços periféricos, assinalando como os efeitos das políticas urbanas excludentes geram desigualdades sociais de toda ordem - econômica, política e cultural.

\section{MATERIAIS E MÉTODOS}

Buscando compreender como o processo de urbanização ocorreu em Viçosa, cidade situada na da Zona da Mata Mineira (Figura 1), este trabalho almejou reconstituir as marcas e os processos que resultaram no nascimento de dois bairros de sua periferia urbana - Amoras e Nova Viçosa. 


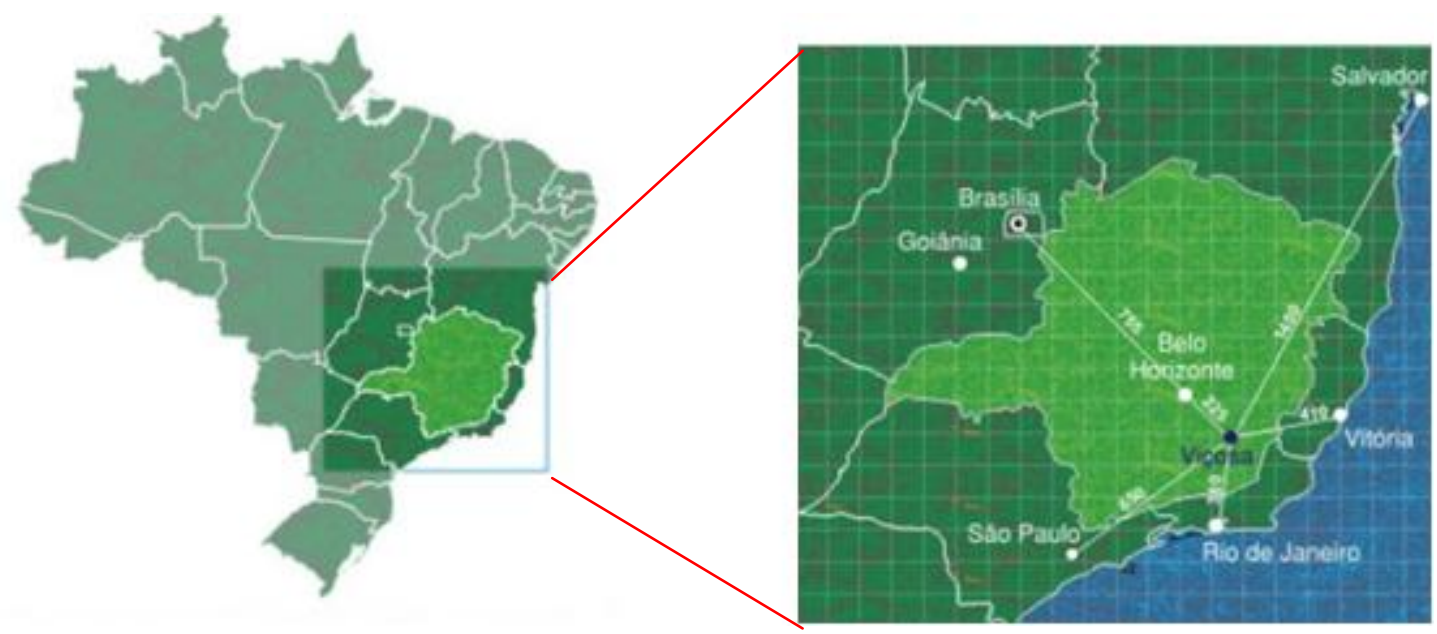

Figura 1. Localização de Viçosa, Minas Gerais. Fonte: Geominas. Composição: R. R. do Carmo. Disponível em: <http://www.vicosa.mg.gov.br/a-cidade/localizacao>. Acesso em: 06 maio 2014.

Para embasar nossas reflexões, adotamos como recorte temporal a década de 1970, momento em que a cidade passa por transformações espaciais significativas em função da federalização da universidade, do desenvolvimento do mercado fundiário, da instalação de novas infraestruturas, da mudança do perfil demográfico provocado pelo crescimento das migrações rural-urbanas e, por conseguinte, pela expansão da malha urbana na cidade. Finalizaremos nossa análise no final década de 1990, quando estes dois bairros/loteamentos se encontravam totalmente instalados.

A pesquisa se apoia em levantamentos realizados nos principais jornais da cidade, no conjunto legislativo, nas informações de vendas e doações dos lotes de Nova Viçosa e Amoras junto Cartório de Registro de Imóveis e ao Escritório do Loteamento Nova Viçosa Ltda. (onde levantamos todas as fichas de cadastro dos lotes doados). Nossa análise foi subsidiada por sucessivos trabalhos de campo e por entrevistas semiestruturadas ${ }^{2}$ realizadas com os moradores dos bairros e com as principais lideranças locais.

\footnotetext{
${ }^{2} \mathrm{~A}$ entrevista é um dos instrumentos básicos para a coleta de dados, pois ela possibilita a interação entre o pesquisador (quem pergunta) e o público alvo (quem responde). Além disso, permite a apreensão imediata e corrente da informação desejada. As entrevistas semiestruturadas são um instrumento flexível, onde há liberdade de percurso para que o entrevistado pondere sobre a temática proposta com base no conhecimento que ele possui (LÜDKE e ANDRÉ, 1986).
} 
É imprescindível destacar que na interpretação dos documentos utilizamos a metodologia denominada análise de conteúdo, objetivando entender os discursos proferidos pelo Estado, proprietários fundiários e promotores imobiliários, bem como a demanda habitacional dos grupos sociais.

Os caminhos propostos e a coleta nas fontes primárias e secundárias elucidaram os elementos que contribuíram, sobremaneira, para a formação das periferias de Amoras e Nova Viçosa. Nesse sentido, as próximas seções têm como objetivo compreender o contexto da cidade de Viçosa nas décadas de 1970 e 1990; a criação de uma legislação proibitiva - que resultou num tipo de ordem espacial que favoreceu os grupos mais capitalizados e induziu a marginalização de outros grupos; as origens fundiárias dos bairros, os motivos que conduziram os migrantes a se deslocarem e os aspectos socioeconômicos destas periferias, bem como as estratégias político-econômicas de Antônio Chequer com a venda e doação de lotes.

\section{RESULTADOS E DISCUSSÃO}

\subsection{A CIDADE DE VIÇOSA NO CONTEXTO DE CRESCIMENTO DAS}

\section{PERIFERIAS URBANAS}

Como lembra Corrêa (2005), as periferias resultam de um processo de expropriação da terra urbana pelo mercado imobiliário e reflete a segregação socioespacial das cidades, ou seja, o projeto de urbanização segregadora. Portanto, "sua geografia guarda [...] estreita relação com as áreas de urbanização mais antiga" (SILVA, 2010, p. 116). Como um fenômeno social de expansão dos núcleos urbanos, a formação das periferias decorre da atuação direta ou indireta do Estado que ora apoia, ora ignora o uso especulativo da terra urbana realizado pelos proprietários fundiários e promotores imobiliários.

Como a intenção final desses agentes é extrair renda da terra, eles são os principais responsáveis pela transformação do espaço rural em urbano. E aproveitando-se da demanda por terras e habitação, que cresce em função da valorização das áreas centrais, estes atores fomentam um mercado de terra para atender as camadas sociais com o nível de renda baixo, em geral ocupadas por 
migrantes e pobres urbanos. Portanto, as periferias urbanas resultam deste jogo social envolvendo Estado, proprietários fundiários, promotores imobiliários e diferentes grupos sociais. Como assume vários significados ${ }^{3}$, incluindo os estigmas ideológicos propagados pelas elites, as periferias, entre outros aspectos, caracterizam-se por serem áreas não servidas de infraestruturas e destinadas às camadas populares da sociedade ${ }^{4}$.

É importante ressaltar que o emprego do termo periférico é sempre relativo, ora sendo apropriado para se referir a uma distância espacial entre lugares da cidade, ora associado à concentração de infraestruturas na área central e ora lido pela ótica de uma cultura que se elege como principal (VALLADARES, 1980). Portanto, o uso do conceito periférico está em consonância com os interesses do enunciador em legitimar uma dada postura em relação ao espaço e aos sujeitos sociais que nele se inserem.

A periferia no Brasil é antiga, no entanto ela se amplia social e espacialmente quando novas áreas da cidade são incorporadas a malha urbana. Sua história de expansão no país vincula-se a um contexto particular onde os projetos de "modernização conservadora" são colocados a cabo, sobretudo após o Golpe Militar ${ }^{5}$. A periferia é, portanto, resultado do crescente fluxo migratório em direção as

\footnotetext{
${ }^{3}$ Chaveiro e Anjos (2007) ao discutirem a definição ideológica da periferia indagam sobre a necessidade de se descortinar o que significa uma área periférica e como tal área pode ser considerada uma área periférica.

${ }^{4}$ Como discute Silva (2010), os subúrbios e favelas são espaços cujas representações sociais muitas vezes omitem os vários fenômenos que ocorrem nestes espaços, processo que alimenta determinados estigmas, que conduzem a um tipo de atuação política sempre marcado por uma visão compensatória e/ou preconceituosa. Nas periferias urbanas das pequenas cidades esse movimento não é diferente, pois as imagens e representações atribuídas a estes espaços historicamente vêm direcionando um tipo de olhar e um tipo de intervenção política, marcado por esse tipo de prática social.

${ }^{5} \mathrm{~A}$ década de 1970 representa o triunfo do projeto de modernização do país, segundo Becker e Egler (1994), caracterizou-se pela via autoritária, sobretudo após o regime militar. Se por um lado, ocorreu um pujante processo de dinamização econômico-industrial, atingindo tanto o parque industrial proeminente grau de complexidade e diversificação como um avanço no setor agrícola, que incorporou novas técnicas, por outro, a maioria da população brasileira não teve acesso aos benefícios deste crescimento econômico. Este processo engendrou uma dualidade, na qual modernidade e pobreza se fundiram em um tecido complexo. Este tecido se configura através de uma estrutura híbrida e instável, entretanto muito dinâmica.Tal fato deixou profundas sequelas na sociedade, tendo impactos nos espaços urbanos e regionais.
} 
cidades, da pobreza no campo e da ausência/pouca incidência de políticas habitacionais nas cidades (SANTOS, M., 2005; MARICATO, 2012).

De uma maneira geral, o aumento da população urbana nas cidades concorreu para formação de espaços onde a pobreza é predominante, devido, principalmente aos problemas relacionados ao acesso ao trabalho, à habitação e as infraestruturas (SANTOS, M., op. cit.).

Analisando o perfil demográfico de Minas Gerais, Santos, M. (op. cit.) destaca que entre os anos 1960-1970 ocorreu a segunda maior perda da população rural do Brasil e que as aglomerações como mais de 20 mil habitantes apresentaram um crescimento expressivo em sua população urbana ${ }^{6}$. Em decorrência do crescimento da pobreza na zona rural dos municípios da Zona da Mata que receberam, durante a década de 1970, grandes levas de migrantes, Viçosa ${ }^{7}$, apresentando 25.784 mil habitantes, teve um comportamento demográfico similar às demais cidades do Brasil e de Minas Gerais; isto é, um aumento representativo de sua população urbana, decorrente dos fluxos migratórios da área rural da cidade e do entorno. Neste aspecto entre 1960-1970 houve um acréscimo de 84,26\% em sua população urbana e uma perda de $24,47 \%$ da sua população rural $^{8}$. Da mesma maneira que outras cidades, em Viçosa os migrantes recém-chegados enfrentaram os mesmos problemas das populações rurais empobrecidas, tornando-se, via de regra, habitantes das periferias.

Constatamos em pesquisa nos bairros de Amoras e Nova Viçosa que os moradores são oriundos, em sua grande maioria, das áreas rurais da própria cidade (Posses, Airões, Violeira, Morro do Café, São José do Laranjal, Barrinha etc) e de

\footnotetext{
${ }^{6}$ Assim, baseando-se em dados estatísticos, o autor mostra que entre 1950-1980 há um aumento de 4,58 vezes da população urbana, ou seja, nesse período "[...] de cada cem novos urbanos, 77 se encontram em cidades e vilas com mais de 20 mil habitantes" (SANTOS, M., 2005, p. 80). Isso significa que a população urbana das aglomerações com mais de 20 mil habitantes cresceu mais rápido que a população total e que a população urbana do país.

${ }^{7} \mathrm{~A}$ cidade de Viçosa localiza-se na Zona da Mata Norte do estado de Minas Gerais. O município pólo da aludida região sedia a Universidade Federal de Viçosa (UFV), criada em 1922 pelo então presidente do estado de Minas Gerais e, posteriormente, presidente da República, natural de Viçosa, Arthur da Silva Bernardes.

${ }^{8}$ Ou seja, saíram da área rural da cidade de Viçosa 2.845 pessoas (PREFEITURA MUNICIPAL DE VIÇOSA).
} 
outras pequenas cidades localizadas na região da Zona da Mata norte, tais como Araponga, Coimbra, Cajuri, Canaã, Ervália, Guaraciaba e São Miguel do Anta. Os principais motivos revelados pelos entrevistados para a vinda em direção a cidade foram: o empobrecimento do campo, a falta de emprego, o acesso a terra e, em menor parte, os motivos pessoais ${ }^{9}$.

Para explicar a continuidade deste fluxo migratório e o crescimento da periferia urbana em Viçosa durante os anos 1970-1980, não devemos deixar de mencionar a importância de alguns eventos locais que se desenrolaram neste contexto, como a federalização da Universidade Rural do Estado de Minas Gerais (UREMG) em 1969. Processo atrelado a grande modernização que ocorria no país, este evento teve impacto direto na nova configuração territorial da cidade, já que há de um lado um expressivo parcelamento dos terrenos (sobretudo os situados nas proximidades da rodovia BR-120, construída na década de 1970) e uma substituição das áreas rurais em áreas urbanas ${ }^{10}$. Por outro lado, a ligação do centro funcional da cidade à universidade, com a ampliação e pavimentação da principal via de acesso (Avenida $\mathrm{PH}$. Rolfs) ${ }^{11}$ concorreu para o deslocamento geográfico do eixo de crescimento e valorização dos terrenos na cidade, agora direcionados para as áreas situadas próximas a esta avenida e à universidade ${ }^{12}$. Portanto, uma das estratégias empregada pelos agentes locais para ampliar sua margem de lucro com a venda

\footnotetext{
${ }^{9}$ Da mesma maneira como analisado por Perlam (1977), a migração dos contingentes populacionais do campo para as cidades também teve como justificativa a busca de melhores oportunidades para a criação dos filhos, já que estes migrantes vislumbravam nas áreas urbanas maior facilidade de acesso à educação e as demais infraestruturas.

${ }^{10}$ Anteriormente à construção da BR-120, o acesso ao centro da cidade ocorria através de um outro caminho. Portanto, a construção dessa via imprime outra centralidade a cidade com implicações na valorização da terra urbana. O asfaltamento das estradas vicinais da região em nove de setembro de 1978 foi um dos últimos atos do governador do estado de Minas Gerais, Levindo Ozanam Coelho. Os trechos asfaltados foram os seguintes: Zito Soares-Piedade de Ponte Nova, Santo Antônio do GramaJequeri, Santa Cruz do Escalvado - MG - 329, Amparo da Serra - Oratórios - MG - 329, Amparo da Serra - BR - 120, São Miguel do Anta - BR-120, Pedra do Anta-Teixeiras - BR-120 e Diogo de Vasconcellos - MG - 262 (JORNAL INTEGRAÇÃO, 1978).

${ }^{11}$ Que desde então passa a ser o principal eixo de ligação da universidade com os bairros.

${ }^{12} \mathrm{Em}$ Viçosa, essas transformações urbanas enquadram-se a dinâmica capitalista do uso do solo, que se estrutura visando construir "desenvolvimentos geográficos desiguais". O interesse como discute Harvey (2004) é a acumulação do capital.
} 
dos terrenos foi à inserção diferenciada do mercado de terras de parcelas do território da cidade.

Dessa maneira, em função do processo de valorização das áreas centrais, a terra rural foi convertida em terra urbana, com a substituição do "uso agrícola da periferia" para uso urbano ${ }^{13}$. Neste movimento nascem respectivamente vários bairros da periferia, entre os quais Nova Viçosa e Amoras: o primeiro do desmembramento da antiga Fazenda "Coelha" e o segundo da colônia agrícola Vaz de Mello. Analisaremos estas e outras práticas espaciais decorrentes deste processo mais adiante.

A ampliação dos cursos na universidade após a sua federalização resultou na criação desses loteamentos e de vários outros. Como discute El-Dine e Alves (2007) o objetivo era abrigar as distintas camadas sociais que se direcionavam em fluxos contínuos para a cidade. Conforme observamos nas informações do jornal Folha de Viçosa $(1978)^{14}$, neste contexto de maior valorização dos terrenos situados nas áreas centrais, nascem as pequenas empresas dos setores imobiliários e construtivos, como a Incorporadora Sena e Figueiredo Ltda., Construtora Delta Ltda., Construtora e Incorporadora Chequer Ltda. e Mundial Ferragens Ltda. Estes setores, que passam a fazer propaganda intensa dos novos loteamentos nos jornais locais, aliados aos donos de terrenos (proprietários de pequenas fazendas e sítios ainda presentes na paisagem de Viçosa) tornam-se os principais responsáveis pela abertura de novas áreas para a venda/aluguel e pelo incremento do mercado imobiliário no final da década de 1970.

Observamos também em pesquisa documental, que paralelamente ao nascimento dos bairros, se instalaram na cidade no ano de 1978 a maior loja de

\footnotetext{
${ }^{13}$ Como nos informa Correia (2005, p. 16), uma das estratégias de valorização da terra é a transformação de áreas rurais em urbanas pelos proprietários fundiários. Via de regra, tal movimento está vinculado ao cálculo elaborado por diferentes agentes do mercado imobiliário em relação à extração da renda fundiária obtida a partir do uso privilegiado.

${ }^{14} \mathrm{O}$ jornal Folha de Viçosa nasce em 1963, sendo seus fundadores o historiador, jornalista e professor Pélmio Simões de Carvalho, Cônego Antônio Mendes e Silas Torres Duarte. A partir desta data passa a ser um dos principais meios de propaganda da cidade e da região, já que circulava semanalmente em Ponte Nova, Raul Soares, Jequeri, Rio Casca, Ervália, Ubá, Teixeiras e Urucrânia. Primeiro o jornal se chamava Folha de Viçosa, depois passou para Jornal Integração e, desde 1986, é denominado Folha da Mata.
} 
material de construção da região (Mundial Ferragens Ltda.) e as agências bancárias do Bradesco, Banco Real e Banco do Brasil (FOLHA DE VIÇOSA, 1978).

É neste contexto de expansão dos setores econômicos ligados a produção, venda e aluguel de habitação que as atividades da Construtora Chequer têm maior impulso. Importa ressaltar que foi durante a primeira gestão do prefeito de Viçosa Antônio Chequer (1973-1976) - que a Construtora de sua propriedade torna-se a principal responsável pela demarcação e venda de vários loteamentos, que se transformaram em futuros bairros da cidade, entre os quais Amoras, Betânia, Santo Antônio, Lourdes, Nova Viçosa, parte do Silvestre e Ramos. Anos mais tarde, a Construtora lança ainda os loteamentos Clélia Bernardes, Prefeito João Braz, Santa Clara (FOLHA DE VIÇOSA, 1978).

Decorrente da prática de apropriação e parcelamento do solo realizada, prioritariamente, pela Construtora e Incorporadora Chequer, durante os anos 1980 grande parte do território do município se transforma em área urbana e é apropriada pela família Chequer.

Dos loteamentos criados, alguns visavam atender o público de maior renda, como o localizado no bairro de Ramos e Clélia Bernardes, outros se destinavam a classe média, como o bairro João Braz e, finalmente, para atender as classes populares, os bairros de Amoras e Nova Viçosa, conforme pode ser observado na Figura 2.

Portanto, a partir da década de 1970 a oferta de terrenos baratos e sem infraestrutura torna a cidade um chamariz para as classes populares em função da constituição e fortalecimento de um mercado imobiliário voltado para esse público. Tal aspecto é revelado na entrevista do presidente da Associação de Moradores do bairro de Amoras, que relata que o terreno onde se instalou o futuro loteamento foi comprado a preços módicos por Antônio Chequer no início da década de 1970 (ANTUNES, 2006). 


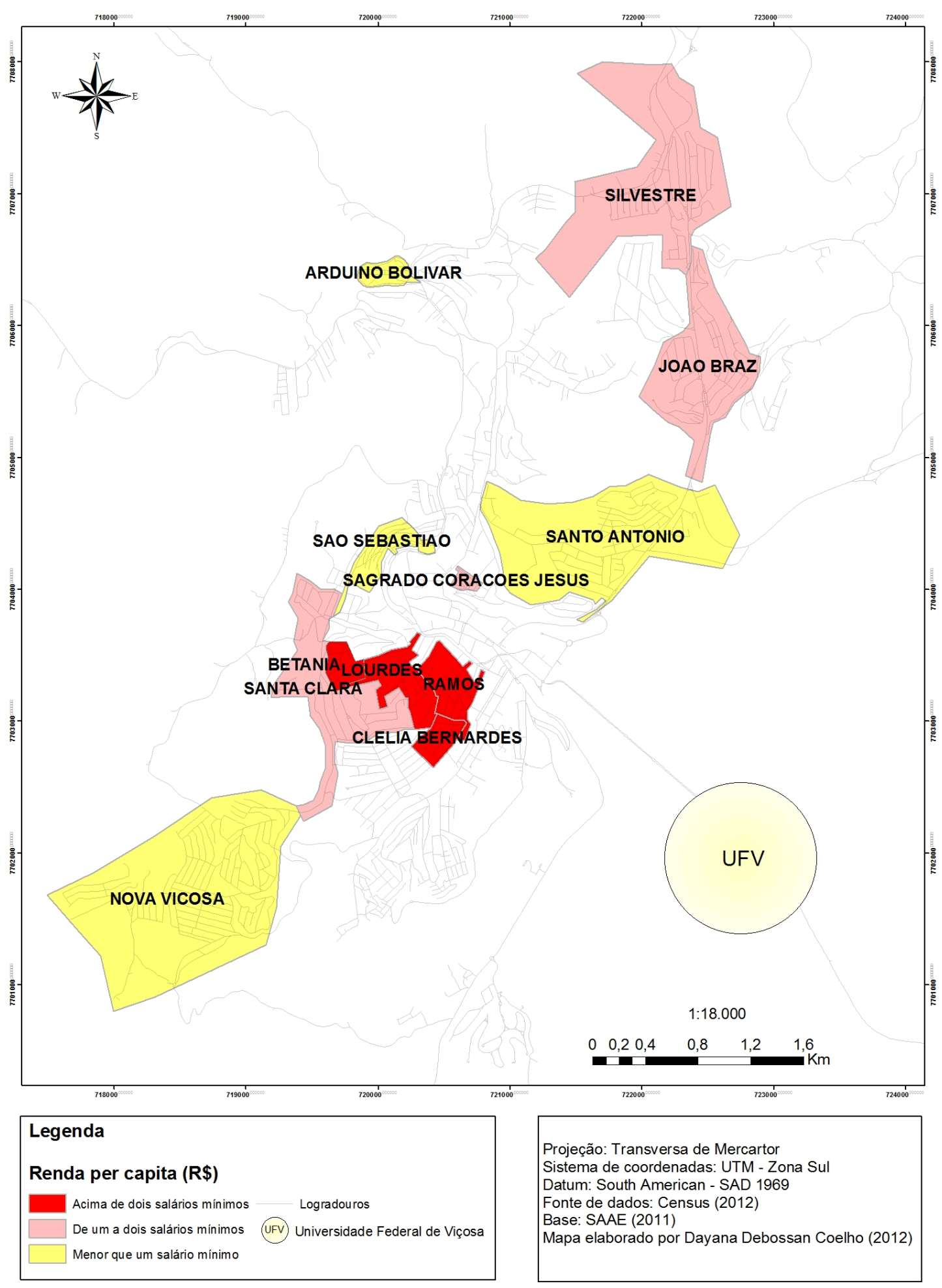

Figura 2. Bairros criados por Antônio Chequer na década de 1970. 
Na maior parte dos casos, o crescimento imobiliário de Viçosa foi resultante da associação de diferentes capitais: o capital financeiro (bancos) e os capitais imobiliários e fundiários (construtoras, em especial, a Construtora e Incorporadora Chequer). O processo de valorização imobiliária (que favoreceu alguns poucos proprietários), a estocagem de terras (o caso de Elias Chequer é ilustrativo já que obteve terrenos em Amoras que ficaram parados há onze anos) e os serviços e equipamentos concentrados nas áreas centrais, demonstram que a obra de alguns agentes foi apropriada de forma "seletiva e desigual". Desta forma, observamos que o movimento de expansão geográfica dos diferentes capitais levou a territorialização de várias áreas da cidade ${ }^{15}$.

Em Viçosa, a periferia geográfica associada à periferia socioeconômica engendrou lugares marginais ao projeto de desenvolvimento apregoado pelas lideranças locais. Em sintonia com as propagandas de progresso e desenvolvimento efetivadas em outras escalas, homens e espaços foram rejeitados pelo modelo econômico e social propalado e bombardeado no contexto de 1980-1990, momento em que se observa um crescimento da mídia local.

\subsection{A proibição de favelas no "coração da cidade" e o surgimento das} periferias

As favelas brotaram como cogumelos e prosperam em número e área rapidamente. Também, se enriqueceram, dia a dia, em problemas de saúde, de alimentação, de vestuário, de escola, de dinheiro, de tudo. Elas é que fornecem o grande contingente diário de casos que vão ter à delegacia de polícia da cidade (FÔLHA DE VIÇOSA, 1971, n 166, s/p.)

(...) quando a Universidade passou a ter um desenvolvimento ainda maior (...) surgiu o Santa Clara, surgiu o "Cantinho do Céu", (...) surgiram loteamentos em Silvestre, o bairro João Brás (...) e finalmente, o bairro Nova Viçosa (...) para impedir que as favelas da cidade crescessem (CHEQUER, 1989 in SANTOS, A. M. C., 1991, grifo do autor).

\footnotetext{
${ }^{15}$ De acordo com Véras (1992) para entender o processo urbanização capitalista é preciso associar as causas estruturais - baixos salários, êxodos rurais, migração massiva, que geram uma pauperização crescente, e as estratégias dos agentes locais, ou seja, de que maneira tanto o mercado quanto ao Estado se organizam e atuam na escala local em associação com as escalas regional e nacional.
} 
Como ilustrado nos trechos acima, multiplicaram-se nas décadas de 1970 e 1980 as matérias e relatos sobre as condições de moradia dos pobres e a necessidade de medidas para resolver os problemas dos "sem teto" no centro da cidade: "é urgente que se faça alguma coisa. Não se consegue sair da rua sem ser abordado, uma dezena de vezes por crianças famintas a mendigar uma moeda (...) mas, o que muitas não sabem é que essas crianças não tem teto" (FÔLHA DE VIÇOSA, 1971, $n^{\circ} 166, \mathrm{~s} / \mathrm{p}$.).

Uma das medidas pensadas, sobretudo após a federalização da universidade, para combater a favelização na área central foi o investimento na compra de terrenos periféricos, situados na zona rural da cidade. A ideia era evitar a ocupação da área central com moradias precárias (favelas). A estratégia realizada pelos setores imobiliários em expansão promoveu ao mesmo tempo a apropriação de vários terrenos no centro da cidade e a ocupação de antigas fazendas. Este aspecto é ilustrado na fala a seguir: "Em Viçosa, as favelas diminuíram consideravelmente. Só para se ter uma ideia Nova Viçosa tem hoje cerca de mil casas. Você já imaginou mais de mil em cima do morro aí, como é que seria?" (CHEQUER, 1989 in SANTOS, A. M. C., 1991, grifo do autor $)^{16}$.

A questão da favelização, que se torna pública através da imprensa, e os principais problemas sociais que abalavam a estabilidade política deram nascimento a Lei Municipal de 31 de dezembro de 1971 ( $n^{\circ}$ 609), que dispunha sobre o Prolongamento de Favelas nas áreas centrais e proibia a construção de casebres no centro. Esta Lei, promulgada na gestão do prefeito Carlos Raymundo Torre (19711972), resultou do debate circunscrito no projeto lei $34 / 71$, que buscava solucionar alguns dos principais desafios enfrentados em Viçosa neste contexto: a valorização dos terrenos na área central, a demanda por habitação para as classes populares, a disputa pela terra urbana e os interesses em ampliar os lucros com a venda e aluguel de imóveis dos nascentes setores comercial e imobiliário.

\footnotetext{
${ }^{16}$ Nesta citação, Chequer se referia ao morro Rebenta Rabicho, localizado no centro da cidade.
} 
Assim, a justificativa apresentada no Projeto de Lei que proibia a proliferação de favelas ancorava-se na ideia de proteger o "coração da cidade de Viçosa" - área circunscrita nas imediações da Praça Silviano Brandão - contra as habitações pobres e insalubres. Portanto, visando impedir a continuidade desta situação, o projeto de Lei previa a proibição de casas de pau-a-pique, pois não se queria "[...] dar sequência á Favela, visto já se encontrar o Morro super habitado e sem nenhuma condição higiênica" (PROJETO LEI 34/71, 1971, sem paginação). $\mathrm{Na}$ opinião dos seus formuladores ${ }^{17}$, a construção de casebres na área central provocaria uma "má impressão" aos turistas que visitavam a cidade, sobretudo em função da proximidade do Morro do Rebenta Rabicho, cuja paisagem de precariedade se sobressaia ${ }^{18}$.

Neste contexto, apesar da existência de vários terrenos vazios na área central, se ergue um dos primeiros acordos da elite local em relação ao uso mais adequado do espaço na cidade: as habitações dos pobres consideradas "antihigiênicas" deveriam ser excluídas do centro "abrindo" novos espaços para as habitações consideradas adequadas, isto é, aquelas compatíveis à nova classe média, que passou a demandar habitação mais próxima à Universidade. As citações a seguir, elaboradas em dois períodos diferentes assinalam dois aspectos que refletiam a preocupação esboçada no corpo da Lei 609 - após a expansão da universidade: a demanda por habitações para o público de classe média e o receio de expansão das áreas pobres.

O professor José Brandão da Fonseca, da UFV, informou (...) que vai receber 120 dos 130 novos alunos dos cursos de pós-graduação, e por isso está fazendo um apelo à cidade a fim de que ela construa hotéis, pensões, apartamentos e casas, para que a Universidade possa continuar mantendo o funcionamento normal de seus cursos pós-graduados (Folha de Viçosa, $1975, \mathrm{~s} / \mathrm{p})$.

\footnotetext{
${ }^{17}$ Dentre os autores deste projeto estão a Comissão de Obras e Serviços Públicos e o vereador Ruy Barbosa Assis de Castro.

${ }^{18} \mathrm{O}$ morro Rebenta Rabicho foi batizado mais tarde de bairro Sagrado Coração.
} 
[...] atraente pela fama de seus muitos estabelecimentos de ensino médio, pela sua universidade federal e pelo crescimento de sua indústria da construção civil, a cidade teve um aumento superior a $100 \%$ em sua população urbana, entre os anos 70 e 80 , e este crescimento extraordinário gerou a riqueza e a expansão do comércio local, mas gerou também problemas de ordem social (...) e a formação de favelas é um desses problemas. No Morro Rebenta Rabicho, por exemplo, a apenas 300 metros do centro cresce uma favela autêntica, na aparência e nos problemas, sem que a maioria da população viçosense tenha conhecimento de sua existência e do perigo que pode representar para o futuro da comunidade (Jornal Integração, 1983, n⿳0169, s/p, grifo do redator).

De um lado construindo mais casas e oferecendo terrenos na área central para atender a demanda de um público de maior renda e, de outro oferecendo, para os pobres, moradias em lugares distantes a baixo custo, entra na cena pública o empresário Antônio Chequer ${ }^{19}$. Sua estratégia empresarial é talvez responsável pelo começo da construção de um mito que vigora até hoje: de ter sido o prefeito a se preocupar com o problema de habitação na cidade e, em especial, por ter sido o único a prover moradias as classes populares, sobretudo após ter doado lotes nos bairros das periferias de Amoras e Nova Viçosa, como veremos a seguir.

3.3. E NASCEM OS BAIRROS POPULARES DE CHEQUER: O CASO DE AMORAS E NOVA VIÇOSA

\begin{abstract}
Nos dois últimos [Arduíno Bolivar e Nova Viçosa], Antônio Chequer praticamente doou lotes urbanizados para as pessoas carentes construírem suas casas. Por este espírito generoso, ganhou popularidade, e a população viçosense soube reconhecer o seu valor como ser humano, despojado dos bens materiais. Muitos o consideravam como "pai dos pobres" (MELLO, 2000, p. 4, grifos nossos).
\end{abstract}

O mito de Antônio como "pai dos pobres viçosense", descrito no trecho acima, esteve relacionado, dentre outros aspectos, a criação dos bairros populares Amoras e Nova Viçosa. Os dois bairros circunscrevem-se nos mesmos processos:

\footnotetext{
${ }^{19}$ Antônio Chequer foi prefeito da cidade de Viçosa durante três gestões: de 1973 a 1976, de 19891992 e 1997. Na última, sua carreira foi política foi interrompida devido a uma parada cardíaca que o conduziu a morte.
} 
conversão do uso agrícola pelo urbano e transformação da moradia em mercadoria de fácil acesso para os pobres.

O bairro de Amoras, designado oficialmente em 1971 como Arduíno Bolivar ${ }^{20}$, era parte de um antigo distrito de Viçosa, tendo sido criado dois anos após a federalização da universidade ${ }^{21}$. Anteriormente, em parte da área que constitui atualmente este bairro, havia uma colônia de imigrantes estrangeiros, denominada Vaz de Melo. Esta era uma propriedade agrícola com cerca de $154.880 \mathrm{~m}^{2}$, onde se praticava agricultura (CADASTRO DE IMÓVEIS DE VIÇOSA, 1971).

De acordo com as informações constantes no Cadastro de Imóveis, Sebastião Maria da Cruz era proprietário da Fazenda Vaz de Melo. Este, através de espólio, deixou sua propriedade em 1979 para seus herdeiros. O posterior parcelamento dessas terras, que ocorreu através de agentes imobiliários desenrolou-se em dois momentos: nos anos 1980, quando os herdeiros venderam parte de suas propriedades para a Empresa Imobiliária Barra Limpa, e a partir dos anos 1990, quando a maior parte das terras foi alienada para a família Chequer ${ }^{22}$.

A década de 1980 é emblemática nesse processo de conversão do uso rural para urbano desta propriedade, pois deflagra a venda e o parcelamento envolvendo agentes ligados ao setor imobiliário, com destaque à Empresa Imobiliária Barra Limpa $^{23}$ que desde 1981 realiza operações imobiliárias na fazenda Vaz de Melo ${ }^{24}$

Conforme podemos observar no Quadro 1, o processo de apropriação dos terrenos da Fazenda Vaz de Melo realizado por iniciativa privada e pública se intensificou nas décadas seguintes, quando as terras foram incorporadas ao

\footnotetext{
${ }^{20} \mathrm{O}$ antigo nome atribuído ao bairro, segundo relatos do presidente da Associação de Moradores, referenciava as várias amoreiras que marcavam a paisagem do local (ANTUNES, 2006). A mudança do nome para Arduíno Bolivar foi uma homenagem prestada por Antônio Chequer a um amigo Arduíno Bolivar, que era professor da Universidade Federal de Viçosa.

${ }^{21} \mathrm{O}$ bairro foi regulamentado pela Lei o 125 de 28 de abril de 1975 pelo prefeito Antônio Chequer.

${ }^{22}$ Informações obtidas junto ao Cadastro de Registro de Imóveis situado no Cartório de Registro de Imóveis, Comarca Viçosa, Minas Gerais.

${ }^{23}$ Nos anos 1980 a maior parte dos compradores de terrenos da Imobiliária Barra Limpa adquiriram glebas de $360.00 \mathrm{~m}^{2}$.

${ }^{24}$ É importante lembrar que os dados se referem apenas as transações imobiliárias realizadas pelo mercado formal.
} 
patrimônio dos seguintes atores: Elias Chequer \& Cia Ltda. ${ }^{25}$, que adquiriu 25.813 m², a Agropecuária Campo Verde Comércio e Representações Ltda., com 255,88 m² e a Prefeitura Municipal de Viçosa com $17.774 \mathrm{~m}^{2}$.

\begin{tabular}{|c|c|c|c|c|}
\hline Ano & Transmitente & Adquirente & Área (ha) & Valor (Cr\$) \\
\hline 1971 & Particular & Particular & 15,49 & $3.697,60$ \\
\hline 1979 & Particular & Particular & 2,58 & $42.219,49$ \\
\hline 1980 & Particulares & Particular & $102.14,34$ & $928.438,98$ \\
\hline 1981 & Particulares & $\begin{array}{c}\text { Particulares e } \\
\text { Empresa } \\
\text { Imobiliária Barra } \\
\text { Limpa } \\
\end{array}$ & $25.814,86$ & $908.719,00$ \\
\hline 1982 & Particular & $\begin{array}{c}\text { Particulares e } \\
\text { Elias Chequer \& } \\
\text { Cia Ltda }\end{array}$ & $25.815,64$ & $1.192 .219,49$ \\
\hline 1983 & $\begin{array}{c}\text { Particular (es) e } \\
\text { Empresa } \\
\text { Imobiliária Barra } \\
\text { Limpa }\end{array}$ & $\begin{array}{c}\text { Empresa } \\
\text { Imobiliária Barra } \\
\text { Limpa e Particular }\end{array}$ & $5.600,05$ & $3.050 .000,00$ \\
\hline 1984 & $\begin{array}{c}\text { Particular (es) } \\
\text { Empresa } \\
\text { Imobiliária Barra } \\
\text { Limpa } \\
\end{array}$ & Particular (es) & $260.818,97$ & $21.732 .719,50$ \\
\hline 1985 & $\begin{array}{c}\text { Particular (es) } \\
\text { Empresa } \\
\text { Imobiliária Barra } \\
\text { Limpa } \\
\end{array}$ & $\begin{array}{l}\text { Particular (es) e } \\
\text { Município de } \\
\text { Viçosa }\end{array}$ & $97.801 .682,00$ & $61.844 .633,00$ \\
\hline 1986 & Particular (es) & Particular (es) & 0,41 & 5.618 .600 \\
\hline 1989 & $\begin{array}{c}\text { Particular (es) } \\
\text { Empresa } \\
\text { Imobiliária Barra } \\
\text { Limpa }\end{array}$ & Particular (es) & 0,95 & $17.534 .500 .000^{*}$ \\
\hline 1990 & $\begin{array}{c}\text { Particular (es) } \\
\text { Empresa } \\
\text { Imobiliária Barra } \\
\text { Limpa }\end{array}$ & $\begin{array}{c}\text { Agropecuária } \\
\text { Campo Verde } \\
\text { Comércio e } \\
\text { Representações } \\
\text { Ltda, Particular } \\
\text { (es) e Município } \\
\text { de Viçosa }\end{array}$ & $15.858,74$ & $2.042 .350,00^{* *}$ \\
\hline $\begin{array}{c}\text { Total de } \\
\text { hectares } \\
\text { transmitidos }\end{array}$ & & $98.135 .610,12$ & $97.642 .771,21$ & $\begin{array}{c}\text { Total de } \\
\text { hectares } \\
\text { transmitidos }\end{array}$ \\
\hline
\end{tabular}

${ }^{*}$ Valor convertido para cruzeiro, pois no ano de 1989 a moeda brasileira era cruzado novo. ${ }^{*}$ Valor convertido para cruzeiro, pois até 15 de março de 1990 a moeda de circulação ainda era o cruzado novo.

Fonte de dados: Cartório de Registro de Imóveis Comarca Viçosa, Minas Gerais. Acervo da pesquisa: Formação de periferias urbanas em Viçosa (MG): os casos de Nova Viçosa e Amoras (1970-1980). Elaborada por Dayana Debossan Coelho (2012).

${ }^{25} \mathrm{Em} 1993$ passou a denominar-se Enfoque Engenharia-Incorporações e Construções Ltda. 
A incorporação dos terrenos pela prefeitura municipal ocorreu em dois momentos: o primeiro, na gestão do prefeito José Américo Garcia (1983-1988), que adquiriu uma área de $7.744 \mathrm{~m}^{2}$ e o segundo em 1990, durante a gestão do prefeito Antônio Chequer (1989-1992), que anexou a estes terrenos uma área de 10.000 m². Parte desses terrenos foi doada pela prefeitura na gestão de Antônio Chequer para a população que se instalou no futuro bairro de Amoras.

Conforme os dados do quadro, podemos observar que no período correspondente há menos de oito anos houve uma elevada valorização dos terrenos dessa propriedade, ou seja, se em 1971 um hectare da propriedade original era vendido pelo valor de 238,86 cruzeiros, em 1979, este mesmo hectare valia $16.364,14$ cruzeiros $^{26}$. Ao revelar o nome dos principais agentes, o quadro indica que os lucros obtidos nas operações de compra e venda foram absorvidos pelos principais setores imobiliários da cidade. Revelam também os dados a imbricação entre a esfera pública e privada, representada neste caso pela família Chequer, cuja prefeitura vai ser assumida entre 1989-1992 pelo dono da Construtora e Incorporadora Chequer.

Cabe ressaltar que no processo de ocupação do bairro, intensificado a partir da década de 1980, não foi instalada nenhuma infraestrutura, e muito menos feita a demarcação de lotes. Em entrevista realizada no bairro de Amoras foi relatado que os responsáveis pela abertura das primeiras ruas foram os próprios moradores.

Passemos para o segundo caso: o bairro Nova Viçosa foi inaugurado oficialmente no dia dezessete de setembro de 1978, conforme matéria divulgada no jornal Integração: "Grande festa no 'Nova Viçosa' dia 17/09". O conteúdo da notícia advertia que a Construtora e Incorporadora Chequer, proprietária da maior parte dos lotes, comemoraria este dia - para ela histórico - com uma "grande festa". Na ocasião, o bairro era considerado pela imprensa o mais arrojado empreendimento imobiliário de toda a região.

\footnotetext{
${ }^{26} \mathrm{Há}$ que ressaltar a diminuição do valor da moeda em função da inflação que acometeu o Brasil no final da década de 1970.
} 


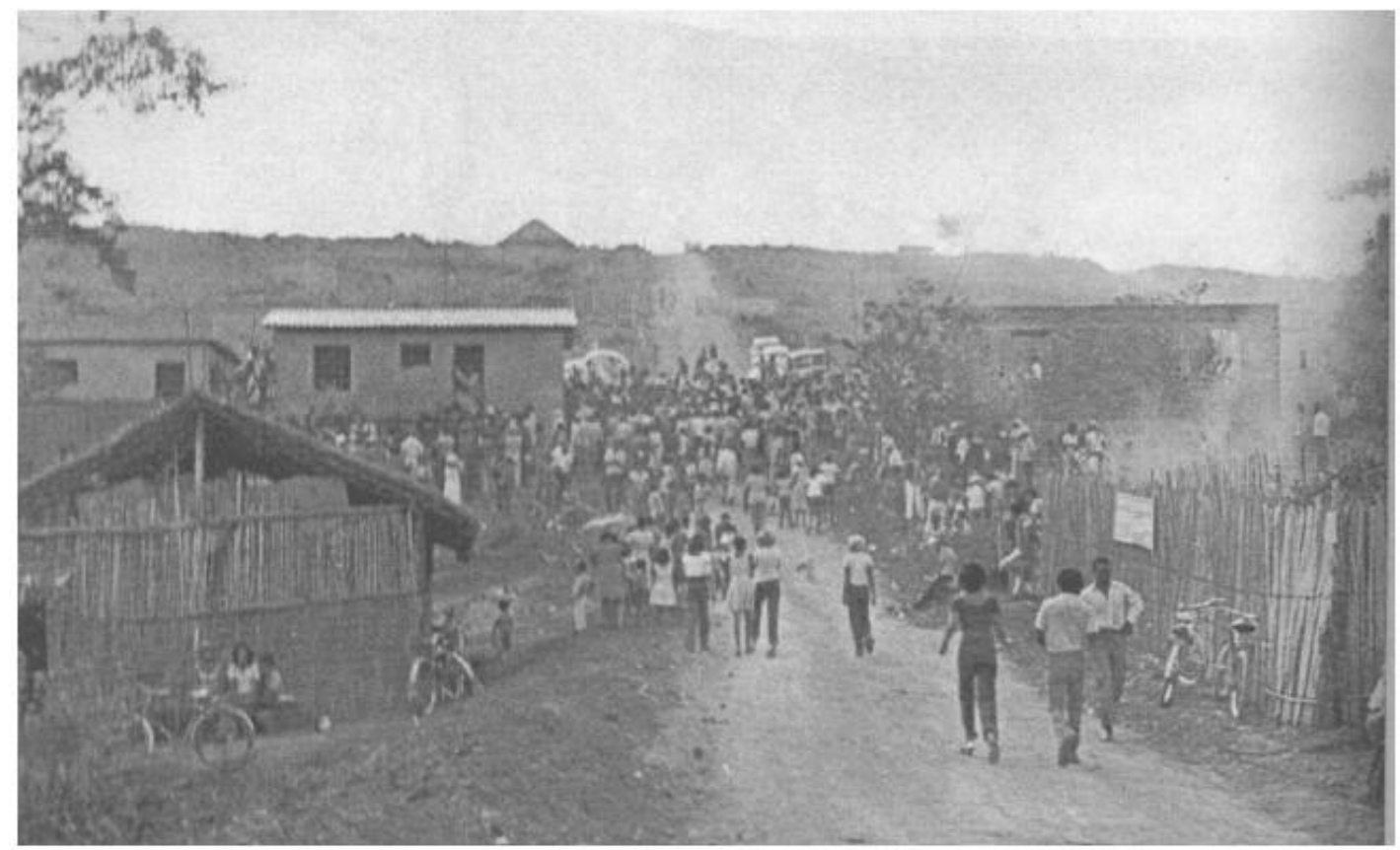

Figura 3. Primeiras casas no bairro Nova Viçosa, Viçosa, Minas Gerais. Fonte: Mello (2000).

No ato de inauguração de Nova Viçosa como pode ser observado na Figura 3 e também através dos relatos dos moradores mais antigos, não havia infraestrutura legal capaz de absorver os novos moradores. Faltavam vias de acesso e as existentes não possuíam pavimentação. Não estavam também instalados os serviços de energia elétrica, água tratada e esgoto como fora prometido pela Construtora Chequer ${ }^{27}$. Além disso, conforme entrevistas e relato do jornal Folha da Mata (1988, s/p), somente dez anos após a instalação dos moradores no bairro é que uma linha de ônibus chegou à sua parte inicial ${ }^{28}$.

Como Amoras, o bairro Nova Viçosa originou-se do processo de parcelamento de duas grandes propriedades rurais: a área originalmente conhecida

\footnotetext{
${ }^{27}$ Este aspecto é referendado na análise de Alves (2007) quando coloca que no processo de propaganda e venda dos lotes, apesar do prefeito Antônio Chequer ter prometido a alocação de infraestrutura no bairro, isto não aconteceu de fato.

${ }^{28} \mathrm{O}$ referido bairro está afastado quatro quilômetros da área central e é isolado por uma montanha, o que contribui para tornar-se mais segregado ainda em relação às demais áreas da cidade.
} 
como Fazenda da Coelha e outra contígua a ela, chamada Pedreira ${ }^{29}$ ou Posses ${ }^{30}$. Esta última propriedade não constava no projeto inicial do Loteamento Nova Viçosa Ltda., no entanto, em 1984 as duas áreas foram registradas em conjunto no Cartório. Este intervalo de seis anos nos revela que houve um descompasso entre a distribuição dos lotes (venda ou doação) e o processo de regulamentação do bairro.

No registro oficial consta que a área total do bairro é de $844.153 \mathrm{~m}^{2}$, sendo constituída pelas propriedades pertencentes ao Loteamento Nova Viçosa Ltda., de Antônio Chequer e a Rafael da Silva Araújo ${ }^{31}$. A Tabela 1 discrimina as áreas pertencentes a estes proprietários ${ }^{32}$.

Tabela 1: Composição do bairro Nova Viçosa em 1984 (ha)

\begin{tabular}{lcc}
\hline Proprietário & Rafael da Silva Araújo & Loteamento Nova Viçosa Ltda \\
\hline Área total & 21,53 & 62,88 \\
Área de ruas & 5,50 & 2,68 \\
Área de lotes & 12,03 & 60,00 \\
Quantidade de lotes & 600 & 3.200 \\
\hline
\end{tabular}

Fonte de dados: Registro Cartório de Registro de Imóveis Comarca Viçosa, Minas Gerais, 1984. Organizada e elaborada por Dayana Debossan Coelho (2012).

Como podemos observar, o Loteamento Nova Viçosa Ltda. detinha a maior área do bairro $(74,49 \%)$, bem como concentrava uma significativa parcela dos lotes $(84,21 \%)$. Como consta nos dados do Cadastro de Imóveis, a área não loteada pertencente a Rafael da Silva Araújo era igual a $40.000 \mathrm{~m}^{2}$, e a pertencente ao Loteamento Nova Viçosa equivalia a $2.000 \mathrm{~m}^{2}$.

\footnotetext{
${ }^{29}$ O Jornal da Folha da Mata (1984), assinala a existência de uma pedreira nos arredores de NovaViçosa, e talvez seja por isso que essa área recebeu tal designação.

${ }^{30}$ Segundo Júlio Bezerra Ferro, corretor de imóveis em Nova Viçosa desde a década de 1990, a comunidade de Posses era e ainda é parte de uma propriedade rural que foi anexada posteriormente ao Loteamento Nova Viçosa Ltda. De acordo com o ex-presidente da Associação de Moradores do bairro, a comunidade de Posses é mais antiga que Nova Viçosa, o que ratifica a informação de Júlio Bezerra Ferro. A atual responsável pela regularização dos lotes pertencentes à família Chequer, afirma que a área de Posses foi comprada e loteada por Antônio Chequer para suprir a demanda de habitação na área.

${ }^{31}$ No documento do cartório consta que a sua profissão era agricultor. Segundo fontes orais, Rafael era um fazendeiro de grande influência na cidade e até hoje seus herdeiros possuem lotes no bairro Nova Viçosa.

${ }^{32} \mathrm{Da}$ área total do bairro, a área ocupada pelas ruas é de $81.808 \mathrm{~m}^{2} \mathrm{e}$ a dos lotes é de $720.345 \mathrm{~m}^{2}$.
} 
Analisando o processo de transformação urbana desta área identificamos nos documentos que o primeiro parcelamento e/ou transmissão das propriedades ocorreu em 1967, sob a forma de herança (inventário e partilha de bens). Nos anos seguintes prevaleceram às transferências dos terrenos através de compra. Conforme mostra o Quadro 2, a Construtora Chequer adquiriu uma área de 107,75 hectares de vários proprietários entre os anos 1978-1984.

\begin{tabular}{|c|c|c|c|c|c|}
\hline Ano & Transmitente & Adquirente & $\begin{array}{l}\text { Área } \\
\text { (ha) }\end{array}$ & $\begin{array}{c}\text { Nome da } \\
\text { propriedade }\end{array}$ & Valor (Cr\$) \\
\hline 1967 & Particulares & Particular & 21,53 & Fazenda da Coelha & - \\
\hline 1978 & Particulares & $\begin{array}{c}\text { Loteamento Nova } \\
\text { Viçosa } \\
\text { (Construtora Chequer) }\end{array}$ & 27,80 & $\begin{array}{c}\text { "Coelha", distrito de } \\
\text { Viçosa }\end{array}$ & $2.000 .000,00$ \\
\hline 1981 & Particulares & $\begin{array}{c}\text { Loteamento Nova } \\
\text { Viçosa } \\
\text { (Construtora Chequer) }\end{array}$ & 52,70 & Pedreira ou "Posses" & $700.000,00$ \\
\hline 1984 & Particulares & $\begin{array}{c}\text { Loteamento Nova } \\
\text { Viçosa } \\
\text { (Construtora Chequer) }\end{array}$ & 3,20 & $\begin{array}{c}\text { "Coelha", distrito de } \\
\text { Viçosa }\end{array}$ & $20.000,00$ \\
\hline 1984 & Particulares & $\begin{array}{c}\text { Loteamento Nova } \\
\text { Viçosa } \\
\text { (Construtora Chequer) }\end{array}$ & 1,17 & "Coelha" & $120.000,00$ \\
\hline 1984 & Particulares & $\begin{array}{c}\text { Loteamento Nova } \\
\text { Viçosa } \\
\text { (Construtora Chequer) }\end{array}$ & 22,88 & "Coelha" & $600.000,00$ \\
\hline $\begin{array}{c}\text { Total de } \\
\text { hectares } \\
\text { transmitidos }\end{array}$ & & & 129,28 & & $3.440 .000,00$ \\
\hline
\end{tabular}

Quadro 2: Transmissão das Propriedades da Fazenda Coelha e de Posses (1967-1984)

Fonte de dados: Registro de Imóveis constantes no Cartório de Registro de Imóveis Comarca Viçosa, Minas Gerais. Acervo da pesquisa: Formação de periferias urbanas em Viçosa (MG): os casos de Nova Viçosa e Amoras (1970-1980). Elaborada por Dayana Debossan Coelho (2012).

Os dados da Tabela 1 e do Quadro 2 demonstram que a apropriação dos terrenos por Antônio Chequer destacou-se durante a década de 1980, o que revela uma estratégia de reserva de valor. Na constituição desse mercado de terras participaram vários agentes: o primeiro representado pelos herdeiros, que eram proprietários de parcelas desmembradas das grandes fazendas. Com o tempo, os herdeiros alienaram estes imóveis para pequenos sitiantes. A partir, sobretudo da década de 1970, estes sitiantes repassaram os lotes para terceiros, para a família 
Chequer e outras companhias imobiliárias, inclusive para a própria Cia. Chequer. A concentração destes lotes a partir de diversas operações de vendas e doações mudou completamente a paisagem, outrora rural, e os personagens envolvidos no uso destes novos espaços.

Dos agentes que se destacam neste mercado de terras cabe assinar o papel político e econômico desempenhado por Antônio Chequer, assim como suas estratégias de visibilidade na cidade e região.

\subsection{IMAGEM E PROPAGANDA DE BENFEITOR: AS ESTRATÉGIAS POLÍTICO-ECONÔMICAS DE ANTÔNIO CHEQUER COM A VENDA E DOAÇÃO DE LOTES}

Nova Viçosa sempre foi a 'menina de seus olhos' e ele sempre teve consciência dos benefícios que ele, naquele momento, prestava a um povo carente e sofrido que necessitava de sua ajuda para, pelo menos, viver sob o seu próprio teto (MELLO, 2000, p. 36).

O uso da propaganda como meio de disseminar a imagem de um homem generoso e um competente empresário da construção civil acompanhou a trajetória política de Antônio Chequer, servindo permanentemente de instrumento em suas campanhas eleitorais para assegurar os seus interesses econômicos. Este aspecto pode ser observado através do relato de seu biógrafo ${ }^{33}$, cuja epígrafe acima reproduz um fragmento.

Para entender a construção da imagem do personagem Chequer é importante pensar nas narrativas que foram forjadas $e$ as intencionalidades muito vezes omitidas nos discursos. Assim, como analisa Bourdieu (1996), devemos desconfiar das narrativas que retratam uma vida de forma coerente e linear, posto que a vida

\footnotetext{
${ }^{33}$ Antônio Oliveira de Mello, nascido em 1939, foi e é uma importante figura no processo de criação e perpetuação da imagem positiva de Antônio Chequer. Redator, e colunista social no jornal Folha da Mata (de maior circulação na cidade) foi responsável em divulgar notícias e feitos sobre o prefeito e sua família desde a década de 1980. Além disso, é também autor do registro fotográfico de vários eventos da qual participaram a família Chequer, assim como pela publicação de dois livros, nos quais se destacam vários episódios do prefeito.
} 
de um personagem está inserida numa trama social bastante complexa. Portanto, via de regra, o que é retratado numa biografia como original e singular, como é o caso dos relatos de Antônio Chequer, são na verdade experiências sociais compartilhadas pelos diferentes membros de uma sociedade. Dessa forma para se compreender a trajetória de Chequer como benfeitor propagada pelos biógrafos e a impressa local, torna-se necessário reconhecermos os contextos e as estratégias discursivas enquanto instrumentos para implementação de alguns projetos.

Neste caso torna-se necessário identificarmos de que maneira este ator utilizou as doações feitas para obter ganhos eleitorais, de outro lado, compreender tais estratégias como práticas clientelistas que foram escamoteadas pela impressa local, principalmente a partir da década de 1970. Neste contexto, os jornais locais e às associações civis, religiosa e militar iniciam pedagogicamente uma campanha em prol de Antônio Chequer, na qual a imagem de protetor dos pobres é ressaltada ${ }^{34}$.

O caso de Nova Viçosa ilustra bem este aspecto. Sua história revela os vários mecanismos empregados pelas elites locais e propagadas pela imprensa para difundir tal imagem. Portanto, a construção deste bairro é o exemplo mais acabado do uso da imagem de benfeitor para consolidar a carreira política de Chequer na cidade e região.

Indícios de que a área que corresponde atualmente ao bairro Nova Viçosa desde o começo era alvo de interesses imobiliários fica expresso no relato fornecido por Antônio Chequer em 1989: “(...) eu levei muitos lá pra ver Nova Viçosa antes de ser e todos diziam: - isso aqui dá um belo cafezal! Eu fechava os olhos e dizia: isto aqui dá um belo loteamento para os pobres!" (CHEQUER, 1989 in SANTOS, A. M. C., 1991).

\footnotetext{
${ }^{34}$ Ao longo de sua carreira Chequer recebeu quatro títulos honoríficos (Título de Figura Marcante de 1977, pela Casa da Amizade, Título do Labor Clube de Viçosa, Título de Sócio Honorário do Diretor Central dos Estudantes da UFV e o Título da Escola Agrícola Arthur Bernardes "Amigo da EAAB") e quatro diplomas (Diploma de Figura Marcante pelo jornal Cidade de Viçosa, Diploma do SENAC, por participação em atividades, Diploma da Secretaria do Interior, pela participação do Encontro que debatia problemas dos municípios, Diploma de Reconhecimento da ACAR - Hoje EMATER). Reforçando a imagem de um homem simples, um homem do povo e para o povo ele recebe também duas premiações: o Certificado de Reconhecimento como Homem Público em 1976 e o de Empresário Destaque de 1978. (JORNAL INTEGRAÇÃO, 1978).
}

R. Ra'e Ga - Curitiba, v.33, p.277-306, Abr/2015 
Essa intenção inicial (transformação da fazenda em loteamento) foi concretizada quando em 1978 ele funda o Loteamento Nova Viçosa Ltda. No entanto, o nascimento ritualizado desta "Nova" Viçosa não representa apenas mais um novo empreendimento. Ele é saldado pela imprensa local como a solução para os problemas dos pobres e sem teto da cidade. A divulgação das matérias de forma reincidente reforça a imagem de Chequer tanto como empresário de prestígio como de benfeitor. A escalada de sucesso nos negócios imobiliários e a força desta imagem concorreram para que o personagem reivindicasse a ocupação de outros espaços na cidade. E é neste movimento que a doação de lotes em Nova Viçosa e Amoras (em menor parte) constitui-se como estratégia central para a consolidação de sua carreira política. Construída em função das doações e da imagem de benfeitor, sua trajetória política omite alguns importantes aspectos: o primeiro é em relação ao número de doações realizadas, ou seja, durante décadas a imprensa divulgou que o total de lotes doados em Nova Viçosa girou em torno de 1.200 a 1.500 , quando na realidade estas as doações não passaram de 281 - quase dez vezes menos do que realmente aconteceu ${ }^{35}$. O segundo é a omissão das condições materiais do terreno e o local das doações: em geral em terrenos íngremes, próximos a brejos, enfim de pouco acesso. $O$ terceiro aspecto relaciona-se com as informações dos jornais que suprimiam o fato de que os terrenos doados e vendidos não tinha valor legal, isto é, muitos destes lotes eram e ainda são de propriedade da Construtora Chequer, pois grande parte dos moradores não possui escritura definitiva. Finalmente, a última omissão refere-se ao apagamento de outros atores sociais que fizeram doações e contribuíram assim para a história de construção deste bairro.

A situação de ilegalidade mantida neste loteamento revela tanto as dificuldades enfrentadas pelos pobres para legalizar sua moradia quanto à ausência

\footnotetext{
${ }^{35}$ As doações eram realizadas através do documento intitulado "Termos de Doação". Para haver um controle destas operações e impedir o recebimento de lotes por pessoas que não necessitavam do auxílio ou por aquelas que não tinham interesse de construir no lote doado, havia cláusulas neste Termo que impediam a venda dos lotes e, também, definiam o prazo máximo para que fossem construídas as moradias no local.
} 
de uma política fundiária de âmbito municipal. Revela também um vínculo histórico de dependência dos moradores em relação ao loteador, já que a regularização dos terrenos e as melhorias de infraestrutura no bairro se tornaram moedas de troca utilizadas por Chequer para obter vantagens nas eleições. Sobre este aspecto cabe assinalar que o primeiro lote de doações começou a ser feito em 1989, quando Chequer ocupava pela segunda vez o cargo de prefeito da cidade. Foi um momento que, aproveitando-se do seu prestígio político, Chequer utilizou as doações para aumentar a sua popularidade. Esta estratégia também foi manejada em 1996 quando concorre pela terceira vez ao cargo de prefeito e em 1997 quando ele assume tal cargo. Nesses dois momentos o número de lotes doados sofre um boom: foram doados em 1996 e 1997, respectivamente 126 e 84 lotes. Cabe ressaltar que a informação obrigatória do número do título eleitoral nas fichas de doação foi uma prática recorrente, sugerindo a política de troca de favores.

Tanto em Nova Viçosa quanto em Amoras a maior parte das operações imobiliárias que prevaleceram foram as vendas. No caso de Amoras, apenas $10 \%$ dos lotes foram doados ${ }^{36}$. Guardadas as devidas diferenças, a história de ocupação de Amoras em muito se assemelha a de Nova Viçosa no que refere à questão das doações, sempre superestimada pela imprensa e história local.

Portanto, a despeito da intensa propaganda em torno da doação de lotes a ocupação desses bairros caracterizou-se pelo emprego de duas estratégias: uma pautada na própria dinâmica do mercado imobiliário, e que se consagra pela captura da renda fundiária obtida pelos lucros com a venda dos terrenos e outra no arranjo político que se estabeleceu através das doações. É uma história que revela o nascimento e a expansão das periferias nas pequenas cidades que em muitos aspectos se assemelha com os processos sociais que se desencadeiam nas médias e grandes cidades.

\footnotetext{
${ }^{36}$ Essa informação foi obtida através de entrevista realizada no bairro, onde o tamanho da amostra foi definido pelo tamanho da população, sendo esta estabelecida pelo total de imóveis edificados no bairro. Verificamos nestas entrevistas que em Amoras $81 \%$ dos lotes foi vendido, enquanto em Nova Viçosa este percentual equivale a $74 \%$.
} 
Os dados e informações revelados nos cartórios, jornais, empresas loteadoras, nos levantamentos de campo e entrevistas demonstram que a conquista da casa própria contou principalmente com o esforço dos moradores, tendo uma participação mínima do Estado. Eles assinalam a ausência de políticas habitacionais voltados para as classes populares e as estratégias dos empresários locais em capturar todos os recursos possíveis para ampliar seus lucros. Portanto, tais informações assinalam as seguintes estratégias empregadas para drenar a renda urbana: conversão das áreas rurais em urbanas, visando à extensão do mercado de terras, apropriação dos terrenos por setores mais capitalizados, objetivando a formação de um estoque de terra e, finalmente, articulação do Estado com os setores imobiliários, que teve como propósito facilitar às transações imobiliárias e o processo de apropriação das terras pelos setores capitalizados.

\section{CONSIDERAÇÕES FINAIS}

A história socioespacial de Amoras e Nova Viçosa serve de exemplo para ilustrar como a federalização da Universidade Federal de Viçosa influenciou nos processos de valorização do espaço e da formação das periferias em Viçosa. Demonstra também como os atores locais (re) significam as estratégias de capitalização adotadas em outras escalas geográficas. O personagem de Antônio Chequer exemplifica estas práticas de capitalização do mercado de terras ao se notabilizar como maior empresário da construção civil. Além disso, seu exemplo demonstra o empoderamento político que foi criado pela imagem propagada pela imprensa e legitimada nas várias campanhas eleitorais. Carregando a bandeira em prol dos menos favorecidos, "dos marginalizados" e oprimidos, as imagens esconderam os benefícios e privilégios conquistados durante a sua trajetória de vida. Neste aspecto omitem os seus interesses de lucro projetados nesses novos espaços periféricos.

A memória construída de Antônio Chequer consagrou uma imagem de pessoa generosa e despojada dos bens materiais, contribuindo para seu processo de mitificação. Além de ter seu nome e de sua família registrado nos bairros, ruas, 
praças e edifícios públicos e privados da cidade, sua memória é sempre acionada pelos seus familiares como forma de consolidar o seu poder político, econômico e simbólico.

Mas o que esconde o mito Antônio Chequer? Os diversos aspectos e tensões existentes da sociedade viçosense relacionados ao problema da habitação e da terra urbana. A solução imaginária criada por este mito alimentou uma prática ainda muito recorrente de troca de favores, constituindo-se numa estratégia para conservar determinados poderes e práticas: dos empresários do setor imobiliário, das empreiteiras e dos políticos populistas. O mito, portanto, criou e ainda recria formas ilusórias para evitar os conflitos e a desagregação da sociedade local.

Ao analisarmos os bairros de Nova Viçosa e Amoras percebemos que 0 poder simbólico exercido por Antônio Chequer com apoio das elites locais invisibilizou os demais sujeitos sociais, consagrando apenas uma versão hegemônica da história destes bairros. Esta versão hegemônica por essência silenciou a história de ocupação omitindo o árduo cotidiano vivenciado pelos moradores durante muitas décadas. Por conseguinte esta versão da história ao dar destaque a apenas um personagem - Chequer - não deixou espaço as outras histórias, acabando por fundir a história dos bairros a sua própria história.

\section{REFERÊNCIAS}

ARQUIVO PÚBLICO MINEIRO. Jornal Integração. Jornais Avulsos Rolo 128. "Folha" de Viçosa. Viçosa, Minas Gerais, 35 mm. Microfilme. 1978.

BRASIL, MINAS GERAIS, VIÇOSA. Lei n. 609, de 30 de dezembro de 1971. Dispõe sôbre "Prolongamento de Favelas", Legislação Municipal, 1971.

BRASIL, MINAS GERAIS, VIÇOSA. Cadastro de imóveis de Viçosa. Cartório de Registro de Imóveis da Comarca de Viçosa - MG, 1985-1990.

BRASIL, MINAS GERAIS, VIÇOSA. Fichas de cadastro dos lotes doados. Escritório do Loteamento Nova Viçosa Ltda, 1989-2012. 
BRASIL, MINAS GERAIS, VIÇOSA. Legislação Municipal de Viçosa. Câmara Municipal de Viçosa, 1970-1980.

BRASIL, MINAS GERAIS, VIÇOSA. Lotações já estão circulando para Barrinha e Nova Viçosa. Folha da Mata. Viçosa, Minas Gerais, 1988.

BRASIL, MINAS GERAIS, VIÇOSA. Prefeitura Municipal de Viçosa. Disponível em: <http://www.vicosa.mg.gov.br> . Acesso em: 12 dez. 2012.

ALVES, N. C. "Um belo loteamento para os pobres": a construção do bairro Nova Viçosa e o imaginário da periferia, 1969-1988. 2007, 70p. Dissertação (Monografia em História) Curso de História. Departamento de História, Universidade Federal de Viçosa, Viçosa-MG, 2007.

ANTUNES, É. P. Segregação Socioespacial Urbana - O caso dos Bairros Arduíno Bolívar - Amoras - e São José - Laranjal, Viçosa-MG. 2006, 77p. Dissertação (Monografia em Geografia) Curso de Geografia. Departamento de Geografia, Universidade Federal de Viçosa, Viçosa-MG, 2006.

BECKER, B. K.; EGLER, C. A. G. O legado da modernização conservadora e a reestruturação do território. In: Brasil - uma nova potência regional na economiamundo. 2 ed. Rio de Janeiro: Bertrand Brasil, 169-213. 1994

BOURDIEU, P. Sobre o poder simbólico. In: O poder simbólico. 16 ed. Rio de Janeiro: Bertrand Brasil, p. 7-16. 2012.

CHAVEIRO, E. F.; ANJOS, A. F. dos. A periferia urbana em questão: um estudo socioespacial de sua formação. Boletim Goiano de Geografia, Goiânia, v. 27, n. 2, p. 181-197. 2007.

CHAUÍ, M. A experiência do sagrado e a instituição da religião. In: Convite à filosofia. 13 ed. São Paulo: Ática, p. 264-267. 2003.

CORRÊA, R. L. Quem produz o espaço urbano? In: O espaço urbano. 4 ed. São Paulo: Editora Ática, p. 11-31. 2005.

EL-DINE, L. R. Z.; ALVES, N. C. A Voz dos Esquecidos: Memória Oral sobre o surgimento da periferia de Viçosa durante o século XX. In: Encontro Regional 
Sudeste de História Oral, 7, 2007, Rio de Janeiro. Anais..., Rio de Janeiro, FIOCRUZ, cd-rom. 2007.

HARVEY, D. Espaços de esperança. São Paulo: Edições Loyola. Brasil, 2004.

LÜDKE, M.; ANDRÉ, M. E. D. A. Métodos de coleta de dados: observação, entrevista e análise documental. In: Pesquisa em educação: abordagens qualitativas. São Paulo: EPU, p. 25-44. 1986.

MARICATO, E. Formação e impasse do pensamento crítico sobre a cidade periférica. In: 0 impasse da política urbana no Brasil. 2a Edição. Editora Vozes: Petrópolis, Rio de Janeiro, 2012.

MELLO, A. O. de. Um Minuto de Silêncio: Homenagem Póstuma a Antônio Chequer. 2 ed. Viçosa: Folha de Viçosa, 180p. 2000.

PERLAM, J. E. O mito da marginalidade: favelas e política no Rio de Janeiro. Rio de Janeiro: Paz e Terra, v. 18. 377p. 1977.

SANTOS, A. M. C. dos. Sociabilidade e ajuda mútua na periferia urbana de Viçosa, Minas Gerais. 1991. 351p. Dissertação (Mestrado em Extensão Rural), Universidade Federal de Viçosa, Departamento de Economia Rural, Viçosa-MG, 1991.

SANTOS, M. A evolução recente da população urbana, agrícola e rural. In: A urbanização brasileira. 5 ed. São Paulo, p. 31-36. 2005.

SILVA, M. L. P. A favela e o subúrbio: associações e dissociações na expansão suburbana da favela. In: OLIVEIRA, Márcio Piñon de, FERNANDES, Nélson da Nóbrega (orgs.). 150 anos de subúrbio carioca. 1 ed. Editora Lamparina, p. 161186. 2010.

VALLADARES, L. do P. Passa-se uma casa: Análise do Programa de Remoção de Favelas do Rio de Janeiro. Rio de Janeiro: Zahar Editores, v. 1. 142p. 1980.

VERÁS, M. P. B.. Cortiços em São Paulo: velhas e novas formas de pobreza urbana e da segregação social. In: A luta pela cidade em São Paulo. BÓGUS, L. M. M.; WANDERLEY, L. E. W. (Org.). São Paulo: Cortez, p. 81-126. 1992. 